\title{
Vittorio Hösle: Kritik der verstehenden Vernunft: Eine Grundlegung der Geisteswissenschaften. C.H. Beck: München 2018, 503 pp., 38,00€ (hardcover), ISBN: 9783406725883
}

\author{
Hans-Ulrich Lessing ${ }^{1} \cdot$ Stefan Reiners-Selbach ${ }^{2}$
}

Published online: 5 February 2021

(C) The Author(s) 2021

At the beginning of May 1883, the first volume of Wilhelm Dilthey's Introduction to the Human Sciences was released. This work carries the subtitle "Essay on the foundation of the historical and social studies". In the dedication to his friend, Count Paul Yorck von Wartenburg, Dilthey writes that he developed his plan for this book in one of their first conversations when he "still dared to call it a critique of historical reason." Dilthey's foundational work for the humanities remained fragmentary, as is known. He could not finish its second volume, which was supposed to contain the actual systematical center, i.e. logic, epistemology, and methodology of the humanities.

135 years after Dilthey, Vittorio Hösle publishes a new foundational work for the humanities, which is evidently committed not only to Dilthey's work. Hösle, who is known for his publications on several philosophical topics, explains his very ambitioned enterprise by alluding to the chaos "in which the humanities bustle at the beginning of the twentyfirst century", "missing any clarity concerning fundamental concepts, methods and tasks" (13). One may detect Hösle's aversion to representatives of post-modernism behind this diagnosis.

Hösle regards hermeneutics to be a subdiscipline of epistemology, which is normative. In his book, he therefore follows Kant, albeit critically, and aligns the structure of his work with the structure of Kants' Critique of Pure Reason.

The main topic of his book is the possibility of intersubjective understanding. His work is meant to be a counter-project to H.-G. Gadamers Truth and Method and an "integral part of the objective idealism of intersubjectivity" (16), which Hösle has been working on for many years. Other than Kant, Hösle's line of argument is mainly influenced by W. James, E. Husserl, J.R. Searle, P. Grice, D. Davidson, O. Scholz, F. Schleiermacher and-despite all criticism - not least by Dilthey.

Hösle's book encompasses three main sections of different extent. The first, long, and constructive section ("analytics of understanding") contains Hösle's philosophical

Hans-Ulrich Lessing

hans-ulrich.lessing@rub.de

1 Department of Philosophy I, Ruhr University Bochum, Universitätsstr. 150, 44801 Bochum, Germany

2 Faculty of Arts and Humanities, Heinrich-Heine University Düsseldorf, Universitätsstr. 1, 40225 Düsseldorf, Germany 
hermeneutics, which is clearly the main subject of his work. In contrast to Gadamer, Hösle defines "philosophical hermeneutics" as the "epistemological justification of principles of understanding and interpretation" (35). It is the discipline to discuss whether and why we can trust our methods of understanding and interpretation to grasp the minds of other persons correctly. The criteria of rationality of understanding correctly, i.e. the "hermeneutical criteria of rationality" (78) are therefore also a crucial topic of this book. In the second section of the book ("dialectic of understanding"), Hösle critically deals with the most important, and to his mind reductionist, hermeneutics. The third section encompasses a "short history of hermeneutics", which Hösle concludes with several theses on the "humanities of the future" (see also Hösle 2020).

The first section, which aims to answer the question of how proper understanding is possible, on the one hand, deals with the clarification of fundamental concepts, the definition of the role of understanding in the context of other processes of knowledge generation, as well as its specific significance and its inherent problems. On the other hand, Hösle gives an overview of objects that can be understood in principle and the fundamental types of understanding. For this, he makes the "transcendentally justified" (49) assumption, that there are other people's minds and mental products that can be understood (see 19, 49). Lastly, in the main part of this section, he discusses the conditions of the possibility of understanding aforementioned objects.

At the beginning of his inquiry, Hösle commences with definitions that are fundamental for his line of argument. Firstly, he specifies the meaning of "understanding". According to him, understanding is the intellectual operation, by which a subject grasps the mental acts of someone not directly present, mainly of another subject (see 21 and 23); it is a kind of empirical knowledge acquisition (see 22), in fact a "very special type of empirical knowledge acquisition"(23). It is different from both external perception and introspection. Since the perception of other people's mental acts mostly happens indirectly, the access to this action is conveyed by perception of sensory objects (see 26). Furthermore, the following notion is important for Hösle: Since other people's minds are not fathomable to me by introspection, I have to rely on my ability to infer their mental state from "the correlation between my own mental states and the perceptible physical states that accompany them" (26). Thus, Hösle rephrases the old model of inference by analogy to understanding, which-among others - underlay Dilthey's theory of understanding other people's minds, developed in his middle period. To Hösle, understanding other people's minds is necessarily determined by one's own experience (see 26, 195, 291, 293).

Hösle differentiates between this subject-centered understanding and three kinds of interpretation, "Auslegen", "Deuten" and "Interpretieren". ${ }^{1}$ While Auslegen denotes a kind of understanding that "focusses primarily on objectivation and is not tied to any subject" (28), Interpretieren only encompasses scientific, i.e. methodical understanding, which explains individual cases by their general principle (see 29, 33, Fn. 19). In contrast, Deuten means "an act of understanding that refers to a mental principle of reality as a whole" (29).

It is obvious that Hösle's concept of understanding is inspired by Dilthey's well-known triad of "life-expression-understanding". Like Hösle, he assumes that understanding is an operation which aims to grasp mental acts of other subjects ("life") that manifest or objectify physically ("expression”).

\footnotetext{
1 Since all three terms Auslegen, Deuten and Interpretieren translate to "interpret", I will treat them as technical terms.
} 
Hösle's next step is the explication of his concept of "humanities". Rather traditionally, he defines them as "the sciences [...] that rely on the operation of understanding - which they usually refine to interpretation [Interpretieren], i.e. the hermeneutical sciences" (36). Hösle's next main thesis, which one could assume obsolete since the later period of Dilthey's work, is that humanities therefore deal with "the mental life of other subjects: In this respect, psychology is the theory of mental life and thus foundational to all humanities" (269).

In his description of the concept of the humanities, Hösle states, by recurring, among others, to Dilthey, that humanities should not be identified with human sciences, since not everything concerning human beings can be understood in this sense, nor can the existence of non-human minds be ruled out. Additionally, he refuses to accept the identification of the humanities with history, as well as the distinction between nomothetic and idiographic sciences as introduced by W. Windelband: The latter contrasts the humanities, defined as describing singular events, with the natural sciences that focus on laws of nature.

To fulfill this complex program of philosophical hermeneutics, Hösle feels obligated to take some preliminary, partly lengthy, theoretical considerations. Since understanding aims at expressions of mental acts or the mind, Hösle is compelled to describe "at least rudiments of a theory of the mind on the one hand, and of the ways it is expressed in the physical world on the other hand" (49f.) in order to determine the nature and the possible objects of understanding.

Hösle's theory of the mind (51-85) is mostly influenced by Husserl's phenomenology of consciousness (see 50). Especially the concept of intentionality and the differentiation of noesis and noema (see 66ff.) are significant for his philosophical hermeneutics.

Furthermore, Hösle gives an overview of the types of expression of the mind (85-154) and differentiates between the expression of affects and emotions, action, works and language. Following this overview, Hösle presents his "typology of modes of understanding" (154-281) in great length. Understanding is defined as an intentional act that aims at something mental, normally at an intentional act of another person (see 155). The perception of its physical manifestation, in which the mind is expressed, remains the necessary condition of understanding. Since the intentional act is composed of noesis and noema this "results in three different entities of an entirely different nature with which the act of understanding has to deal: something physical, something mental and something noematic" (155). Hösle calls the kinds of understanding that in turn focus on one of these aspects "perceptual", "noetic" and "noematic" understanding (156). Perceptual understanding focusses on the physical medium (159-168), noetic understanding on the noetic act (168-174) and noematic understanding concentrates on the noema of the act (174-179). This distinction is complemented by an overview of understanding of the four kinds of expression of the mind (affects, action, works and language) while Hösle's explanation of the understanding of works deserves special attention (202-214).

The understanding of works, which is at the heart of humanist practice and which is the "actual sphere of noematic understanding" (209), has to abstract from the "creation of a work while, in the case of a scientific work, focusing on the coherence of reasoning or, in the case of a work of art, on its aesthetic qualities" (203). According to Hösle, a work in the emphatic sense exists, if extraordinary mental acts of its author are expressed in it (see 204). His main thesis is that a work is an "expression of a mental act, of a will to a work [...], which is in turn founded on perceiving natural objects, other works of art, aesthetical decisions, or most often on being fascinated by a subject matter and the rejection of its realization by other artists" (205). However, this does not mean that the understanding of a work can solely expose an author's intentions; it can find aspects unknown or obscure 
to the author. A work can hold a potential for meaning that surpasses the original author's intention (see 206-213, 240f., 255). Of course, these findings are not innovative. They show that "moderate intentionalism" (155; see also 239), which Hösle endorses, leaves "surprisingly much room for the integration of anti-intentionalist hermeneuticians" (155; see also 240).

Hösle's thoughts on the understanding of a work turn to the "main question of every theory of hermeneutics [...], namely to what extent successful understanding has to be guided by the author's intention and to what extent it may transcend it" (155). This main problem of hermeneutics, "to what extent valid understanding is reliant on the reconstruction of the author's intention" (237), Hösle answers with a demand, that Dilthey already made in his paper "The Rise of Hermeneutics" (1996): "It seems to me that the restoration of criteria that separate valid from invalid interpretation is imperative, if the humanities shall not succumb to the complete arbitrariness of individual opinions" (238). According to Hösle, an important, albeit not the only criterium of valid understanding is "certainly the author's intention" (238).

Valid understanding renders necessary the adherence to the long catalogue of criteria, which Hösle develops in his section on understanding of language (214-237). Among other things, this encompasses the assumption of intended truthfulness when it comes to serious authors (234) and the "consideration of the work as a whole" (234; see also 236, Fn. 231). Although he acknowledges the limitations of radical intentionalist hermeneutics, Hösle nonetheless adheres to the notion that "the understanding of another person's intention is one of the main tasks of hermeneutics" (239). Thus, the aim of hermeneutics is to understand an author, and understanding is per se aimed at the individual intention of an author (see 278).

Hösle's project of philosophical hermeneutics relies on the necessary precondition that "there is something mental that is verifiable" (277). A second (metaphysical) consideration follows: The mind's dependence on matter has to be compatible with this postulated verifiability, i.e. "the laws of the physical world have to be shaped in such a way as to generate truthful mind" (278). Therefore, Hösle deduces, that nature itself is dependent on a principle that requires mind (see 278).

This paves the way for Hösle's answer to the actual philosophical question of how understanding is possible (see 281). He addresses this question with an 'objective-idealistic' approach (282). Just as Kant assumes the fact of natural sciences, Hösle assumes the "fact of understanding (in our lifeworld as in the humanities)" (281) and searches for the conditions of its possibility. The "precondition of understandability" (284) or the "inevitability of the fact of understanding" (288) are decisive for his theory. However, Hösle's approach differs from Kant's program in four points, while the following is the main difference: Whereas Kant follows a transcendental-idealistic approach, Hösle favors an objective-idealistic program (282-285). The twist of this approach is the assumption of "objective reason, which is not the result of temporary processes, but the foundation of these processes as well as of the principle of physical existence" (284). In other words: "That physical reality can in principle be accessed by a conscious mind, which itself is graspable by another conscious mind, is an expression of a principle of First Philosophy, overarching being, thinking and communication, which can be grasped by reflective arguments" (284).

The actual theory of understanding that has to answer the question of how mental acts have to be composed to be understandable (see 288f.) is structured triadically: "transcendental aesthetics, logic and pragmatism of hermeneutics" (288). Since understanding is only possible if physical objects are perceived-because only this perception enables the comprehension of other minds - transcendental aesthetics of hermeneutics examines 
the three kinds of physical objects or physical expression (see 290). The starting point of understanding according to Hösle is my own mental life, only directly accessible to me, known to me by introspection, from which I infer to other minds by analogy (see 291, 293, 296). Therefore, transcendental aesthetics of hermeneutics assumes that "general psychophysical laws" of correlation between mental and physical states exist (295; see also 296, 314).

Transcendental logic of hermeneutics addresses the problem of how verbal utterances of another person can be understood (see $301 \mathrm{ff}$.). It mainly arrives at a solution via D. Davidsons transcendental "principle of charity" (307; see also 474), i.e. the assumption of rationality, truthfulness, and coherence of speech acts of other people. Transcendental pragmatism of hermeneutics, which addresses the social dimension of understanding, aims "to express which parts of the linguistic turn of Karl-Otto Apel's transcendental pragmatism seem plausible" (289; original emphasis). In a nutshell, pragmatism means the assumption of rationality of action, when it comes to other people (see 320). Also, "social intelligence" is assumed which means "that another person does not simply speak the truth but speaks comprehensibly" (324). For, they have an elemental interest in being understood; since otherwise the purpose of communication cannot be achieved (see 327).

In the second section of his book ("dialectics of understanding"), Hösle gives a critical overview of the most important reductionist hermeneutics. He lists three main types: "behaviorist hermeneutics which mainly focusses on observable behavior [...], noetic hermeneutics which is primarily interested in the mental act, its causes and effects, and noematic hermeneutics which is led by the noema to its explication - without questioning or trying to understand where the line between explicit and implicit noema is" (334). Behaviorist hermeneutics is represented by Quine's theoretical concept (see 335ff.) and noetic hermeneutics by Dilthey's work (see 340ff.). However, Hösle omits the fact that Dilthey $(1927,84 f$.) argues for noematic hermeneutics in his later period. To him, noematic hermeneutics is represented by Leo Strauss' "hermeneutics of persecution" (see 380ff.) and the poststructuralism or deconstructivism of R. Barthes and J. Derrida (see 389ff.).

On the one hand, Hösle's book impresses with stunning erudition and plentiful information. The author proves himself not only philosophically educated but shares his profound knowledge of many disciplines of - not only — the humanities (e.g. theology) with the reader. On the other hand, one might be led to think of it as too much of a good thing. Strong points of the book are its systematical structure, its lucid stylistic composition and its amalgamation and skillful integration of numerous philosophical and scientific concepts and results into its own project. However, a more concise line of thought and concentration on its main topics would have been helpful.

Weak points of the book are its exceeding theoretical efforts and its problematic justification of the humanities by an objective idealism. One can rightly doubt whether it is possible to found philosophical hermeneutics on objective-idealist metaphysics since Dilthey's "phenomenology of metaphysics". Furthermore, Hösle's concept of the humanities seems obsolete since he reduces it to the observation of mental acts. Accordingly, Hösle conceptualizes understanding as the reconstruction of other people's minds and not as the exposure of meaning. Ultimately, the function that Hösle ascribes to psychology in his foundational work is objectionable: According to him, the human sciences work on the mental life of other persons, and therefore psychology as the science of mental life is the basis of all humanities.

Since, according to Hösle, understanding is focused on an individual author's intention and the aim of the humanities is the analysis of the mens auctoris, his hermeneutics is confronted with the main problem of every, however moderate, intentionalist hermeneutics: 
Are there reliable criteria for a "correct interpretation"? Are there clear criteria for the decision between valid and false conceptions of the author's intention? How could one verify whether my interpretation corresponds to the author's intention? The problem becomes apparent in its entirety especially when Hösle addresses oral (and written) epic poetry. Is it reasonable to speak of an author's intention regarding the Nibelungenlied, especially since its author is unknown and it is unclear how many authors worked on it? Hösle's solution to this problem is rather lacking in complexity: "The first author is responsible for what he produced, the second one mainly for what he added but also for integrating it into the earlier text" (257). But is the situation any better when it comes to poetry? Could one grasp a clear author's intention in Hölderlin's Andenken or Paul Celan's Atemkristall? These are questions which, one could assume, modern philosophical hermeneutics should be able to answer.

Funding Open Access funding enabled and organized by Projekt DEAL.

Open Access This article is licensed under a Creative Commons Attribution 4.0 International License, which permits use, sharing, adaptation, distribution and reproduction in any medium or format, as long as you give appropriate credit to the original author(s) and the source, provide a link to the Creative Commons licence, and indicate if changes were made. The images or other third party material in this article are included in the article's Creative Commons licence, unless indicated otherwise in a credit line to the material. If material is not included in the article's Creative Commons licence and your intended use is not permitted by statutory regulation or exceeds the permitted use, you will need to obtain permission directly from the copyright holder. To view a copy of this licence, visit http://creativecommons.org/licenses/by/4.0/.

\section{References}

Dilthey, W. (1927). Der Aufbau der geschichtlichen Welt in den Geisteswissenschaften. In B. Groethuysen (Ed.), Gesammelte Schriften VII. Leipzig/Berlin: Vandenhoek \& Ruprecht.

Dilthey, W. (1996). The Rise of Hermeneutics. In R. A. Makkreel \& F. Rodi (Eds.), Hermeneutics and the study of history (pp. 235-260). Princeton: Princeton University Press.

Hösle, V. (2020). Was sind und zu welchem Ende studiert man Geisteswissenschaften? In H. Joas \& J. Noller (Eds.), Geisteswissenschaft: Was bleibt? Zwischen Theorie, tradition und transformation (pp. 104-134). Freiburg/München: Herder.

Publisher's Note Springer Nature remains neutral with regard to jurisdictional claims in published maps and institutional affiliations. 